\title{
Reconciling pH for Ammonia Biofiltration and Cucumber Yield in a Recirculating Aquaponic System with Perlite Biofilters
}

\author{
Richard V. Tyson ${ }^{1,2}$, Eric H. Simonne, and Danielle D. Treadwell \\ Horticultural Sciences Department, University of Florida, Gainesville, \\ FL 32611
}

James M. White

Mid-Florida Research \& Education Center, University of Florida, Apopka, FL 32703

\section{Amarat Simonne \\ Family, Youth and Community Sciences Department, University of Florida, Gainesville, FL 32611}

Additional index words. nitrifying bacteria, nitrification, hydroponics, aquaculture, sustainable agriculture, most probable number

\begin{abstract}
Integrating hydroponic and aquaculture systems (aquaponics) requires balanced $\mathrm{pH}$ for plants, fish, and nitrifying bacteria. Nitrification prevents accumulation of fish waste ammonia by converting it to $\mathrm{NO}_{3}{ }^{-}-\mathrm{N}$. The difference in optimum $\mathrm{pH}$ for hydroponic cucumber (Cucumis sativa) (5.5 to 6.0) and nitrification (7.5 to 9.0) requires reconciliation to improve systems integration and sustainability. The purpose of this investigation was to: 1) determine the ammonia biofiltration rate of a perlite trickling biofilter/root growth medium in an aquaponic system, 2) predict the relative contribution of nitrifiers and plants to ammonia biofiltration, and 3) establish the reconciling $\mathrm{pH}$ for ammonia biofiltration and cucumber yield in recirculating aquaponics. The biofiltration rate of total ammonia nitrogen (TAN) removal was 19,31 , and $80 \mathrm{~g} \cdot \mathrm{m}^{-3} \cdot \mathrm{d}^{-1}$ for aquaponic systems [cucumber, tilapia (Oreochromis niloticus), and nitrifying bacteria (Nitrosomonas sp. + Nitrobacter sp.)] with operating $\mathrm{pH}$ at 6.0, 7.0, and 8.0, respectively. With the existing aquaponic design (four plants/20 L perlite biofilter/100 $\mathrm{L}$ tank water), the aquaponic biofilter (with plants and nitrifiers) was three times more effective at removing TAN compared with plant uptake alone at pH 6.0. Most probable number of Nitrosomonas sp. bacteria cells sampled from biofilter cores indicated that the aquaculture control (pH 7.0) had a significantly higher (0.01\% level) bacteria cell number compared with treatments containing plants in the biofilter (pH 6.0, 7.0, or 8.0). However, the highest TAN removal was with aquaponic production at $\mathrm{pH}$ 8.0. Thus, operating $\mathrm{pH}$ was more important than nitrifying bacteria population in determining the rate of ammonia biofiltration. Early marketable cucumber fruit yield decreased linearly from 1.5 to $0.7 \mathrm{~kg} / \mathrm{plant}$ as pH increased from 6.0 to 8.0 , but total marketable yield was not different. The reconciling $\mathrm{pH}$ for this system was $\mathrm{pH} \mathrm{8.0,} \mathrm{except} \mathrm{during} \mathrm{production} \mathrm{for} \mathrm{early-season}$ cucumber market windows in which $\mathrm{pH} 7.0$ would be recommended.
\end{abstract}

Aquaponics is the integration of hydroponic and aquaculture systems. Cucumber (Cucumis sativus) is an important hydroponic greenhouse crop (Tyson et al., 2001) with potential for production in aquaponic systems (Timmons et al., 2002). Worldwide

Received for publication 28 Dec. 2007. Accepted for publication 12 Feb. 2008.

We thank Megan Davis and Frank Chapman for their assistance with the aquaculture subsystem and Wei-Yea Hsu for her guidance with the MPN procedures.

${ }^{1}$ Present address: Richard V. Tyson, University of Florida, Seminole County Extension, $250 \mathrm{~W}$. County Home Road, Sanford, FL 32773.

${ }^{2}$ To whom reprint requests should be addressed; e-mailrvt@ufl.edu production of tilapia (Oreochromis sp.) exceeded 2.2 million metric tons in 2002 with $68 \%$ of that total coming from farmed aquaculture (Lim and Webster, 2006). Properly designed and managed hydroponic and aquaculture systems are considered environmentally responsible alternatives to fieldgrown vegetable production and wild-caught fisheries (Smither-Kopperl and Cantliffe, 2004; Timmons et al., 2002).

Aquaponics fits closely into the definition of sustainable agriculture in the 1990 USDA Farm Bill (Gold, 1999) because it combines plant and animal production, integrates natural biological cycles, and makes the most use of nonrenewable resources. It has the potential to become a near-zero agricultural discharge production system, significantly reducing wasteful effluent discharges to the environment. However, with all its promise, limited information is available on nitrification rate in a perlite biofilter/root growth medium or on the interaction and competition between plant roots and nitrifying bacteria for ammonium. Also, there is no scientifically established reconciling $\mathrm{pH}$ for these operating systems, which contain plants, fish, and nitrifiers - each with their own optimum environmental requirements. Recommended $\mathrm{pH}$ for tilapia is 6.0 to 9.0 (Popma and Masser, 1999), for greenhouse cucumber is 5.5 to 6.0 (Hochmuth, 2001), and aquaculture biofilter nitrification was reported to be most efficient between 7.5 and 9.0 (Hochheimer and Wheaton, 1998).

One important subsystem of recirculating aquaculture systems is the biofiltration of fish waste ammonia through nitrification to maintain fish tank water quality (Gutierrez-Wing and Malone, 2006; Masser et al., 1999). This is necessary because $10 \%$ of the protein in fish feed becomes ammonia in the system water (Timmons et al., 2002) and unionized ammonia $\left(\mathrm{NH}_{3}\right)$ is toxic to fish at levels above $0.05 \mathrm{mg} / \mathrm{L}$ (Francis-Floyd and Watson, 1996). Nitrification is the biochemical conversion by bacteria of $\mathrm{NH}_{3}$ to $\mathrm{NO}_{3}^{-}$(Hagopian and Riley, 1998; Madigan et al., 2003; Prosser, 1986). It is a two-step process:

Primarily Nitrosomonas sp.

$$
\begin{aligned}
\mathrm{NH}_{3}+1 \frac{1}{2} \mathrm{O}_{2} \leftrightarrow & \mathrm{NO}_{2}^{-}+\mathrm{H}_{2} \mathrm{O}+\mathrm{H}^{+} \\
& +84 \mathrm{kcal} \mathrm{mol}^{-1}
\end{aligned}
$$

Primarily Nitrobacter sp.

$$
\mathrm{NO}_{2}{ }^{-}+1 / 2 \mathrm{O}_{2} \leftrightarrow \mathrm{NO}_{3}{ }^{-}+17.8 \mathrm{kcal} \mathrm{mol}^{-1}
$$

Nitrate, the end product of nitrification, is not toxic to fish except at very high levels (channel catfish, Ictalurus punctatus, 96-h LC50 > $6200 \mathrm{mg} \cdot \mathrm{L}^{-1} \quad \mathrm{NO}_{3}-\mathrm{N}$; Colt and Tchobanoglous, 1976). Nitrate is the primary source of nitrogen for plants in hydroponic nutrient solutions at concentrations from 50 to $280 \mathrm{mg} \cdot \mathrm{L}^{-1} \mathrm{NO}_{3}-\mathrm{N}$ (Resh, 2004). Hence, the understanding and management of the nitrification process in aquaponics is important for the maintenance of water quality and the production of nitrate nitrogen.

In water, ammonia exists in two forms, which together are called the total ammonium nitrogen (TAN) (Francis-Floyd and Watson, 1996) $\left(\mathrm{TAN}=\mathrm{NH}_{4}^{+}+\mathrm{NH}_{3}-\mathrm{N}\right)$. The equilibrium reaction is as follows (Campbell and Reese, 2002): $\mathrm{NH}_{4}^{+} \leftrightarrow \mathrm{NH}_{3}+\mathrm{H}^{+}$. Plants absorb the ammonium $\left(\mathrm{NH}_{4}^{+}\right)$form (Marschner, 2003) and the unionized ammonia $\left(\mathrm{NH}_{3}\right)$ is the substrate ion used for the nitrification reaction (Madigan et al., 2003; Prosser, 1986). Because in water they are in equilibrium, removal of either nitrogen form will result in a reduction of the other. Water temperature and $\mathrm{pH}$ will affect which form of ammonia is prevalent (Lim and Webster, 2006). At $22{ }^{\circ} \mathrm{C}$, the unionized ammonia 
fraction is $0.46 \%$ and $4.4 \%$ of TAN for $\mathrm{pH}$ 7.0 and 8.0, respectively (Francis-Floyd and Watson, 1996). This represents nearly a 10 -fold increase in unionized ammonia substrate for the nitrification reaction as $\mathrm{pH}$ increases one unit. Increased removal of ammonia by a trickling biofilter was found with increasing concentrations of ammonia in pond water (Rijn and Rivera, 1990) and removal rate was considered substrate-limited with respect to ammonia.

Plant uptake is one of the most widely recognized biological processes for contaminant removal in wastewater treatment wetlands (Debusk, 1999; Mitsch and Gosselink, 2000). Ammonium nitrogen removal efficiencies of $86 \%$ to $98 \%$ were reported from a constructed wetland system receiving aquaculture wastewater (Lin et al., 2002). In hydroponic greenhouse plant production systems receiving aquaculture wastewater (Adler et al., 1996), differences in nutrient removal rates of nitrate nitrogen and phosphorus were dependent on plant numbers and effluent flow rate. If plant numbers are increased sufficiently, nutrient concentration can decrease to levels that may be too low to sustain plant growth. Aquaponic wastewater cleanup cost abatement alone can be a major factor in integrating hydroponic and aquaculture systems (Adler, 2001; Adler et al., 2000). Plant roots were found to be more competitive for ammonium than the ammoniaoxidizing bacterial species Nitrosomonas europaea (Verhagen et al., 1994). There may be a possibility for less reliance on nitrification in aquaculture biofilters for ammonia removal when sufficient plants are present in aquaponic systems. More work needs to be done to understand these relationships and thus optimize the biological efficiencies of the organisms through management practices.

The most probable number (MPN) technique is a method of estimating the numbers of microorganisms in foods, wastewater, enrichment cultures, or natural samples of water or soil (Madigan et al., 2003). A selective culture medium is prepared to target the growth of specific organisms or groups of organisms such as nitrifying bacteria. The MPN method has been used to enumerate nitrifying bacteria in sediments of aquatic environments (Feray et al., 1999; Smorczewski and Schmidt, 1991) and terrestrial soils (Papen and von Berg, 1998; Prosser, 1986). It has also been used in a hydroponic system (Schwarz et al., 1999) and in soilless potting media (Lang and Elliott, 1997). MPN bacterial cell numbers can be used to compare the relative production environment effects on bacterial population growth provided initial cell inoculation numbers are the same among treatments.

A dichotomy exists between $\mathrm{pH}$ optima for hydroponic cucumber growth $(\mathrm{pH} 5.5$ to 6.0) and nitrifying bacteria activity ( $\mathrm{pH} 7.5$ to 9.0 ). However, no scientifically based $\mathrm{pH}$ optima for aquaponics has been established. Plants and nitrifying bacteria both contribute to the biofiltration of fish waste in aquaponic systems. However, little is known about how aquaponic cucumber and nitrifying bacteria are affected by operating outside their recommended $\mathrm{pH}$ ranges and how this affects fruit yield and ammonia biofiltration. The purpose of this investigation was to: 1) determine the ammonia biofiltration rate of a perlite trickling biofilter/root growth medium in an aquaponic system, 2) predict the relative contribution of plants and nitrifiers to the biofiltration of ammonia, and 3) establish the reconciling $\mathrm{pH}$ for ammonia biofiltration and cucumber yield in recirculating aquaponics.

\section{Materials and Methods}

The growout phase of the experiment was conducted in a pad and fan greenhouse with polyethylene cover at the University of Florida Horticultural Sciences Department Teaching Park, Gainesville, FL, from 6 July to 12 Oct. 2006. Treatments were aquaponic systems with operating $\mathrm{pHs}$ of $6.0,7.0$, and 8.0 and controls consisting of a hydroponic system at $\mathrm{pH} 6.0$ and an aquaculture system at $\mathrm{pH}$ 7.0. Aquaponic treatments consisted of cucumber, tilapia, and inoculation with nitrifying bacteria. The hydroponic control contained cucumber plants only, and the aquaculture control contained tilapia and nitrifying bacteria. The laboratory phase of the experiment to determine MPN estimates of the Nitrosomonas sp. bacterial cell populations in the biofilters was conducted from 12 Oct. to 20 Nov. 2006.

Each greenhouse plot consisted of a recirculating tank with a crate containing $20 \mathrm{~L}$ of perlite suspended above the tank. Recirculating tanks were placed $75 \mathrm{~cm}$ on center down a single row in the greenhouse running parallel to the north-south sidewalls. Each circular tank (180 L, model DM52; Aquatic Ecosystems, Apopka, FL) was filled with $100 \mathrm{~L}$ of well water on 6 July 2006. Biofilters consisting of rectangular plastic milk-carrying crates lined with natural burlap and filled with $20 \mathrm{~L}$ of horticultural-grade perlite were placed on top of the recirculating tanks on 13 July. One aquarium pump (model HX2500; Aquatic Eco-systems) was placed in the bottom of each tank and water was recirculated (beginning on 13 July) to distribution plates on top of the perlite in the biofilter and allowed to trickle down through the perlite back to the tanks at an average rate of $100 \mathrm{~L} \cdot \mathrm{h}^{-1}$. An additional pump (model SP800; Aquatic Eco-systems) was added on 30 Aug. to each tank to increase water turnover rates through the biofilter to an average of 300 $\mathrm{L} \cdot \mathrm{h}^{-1}$.

Phosphoric acid was used to lower water $\mathrm{pH}$ and potassium hydroxide was used to raise $\mathrm{pH}$ to treatment levels (target 6.0, 7.0, and 8.0). An ammonia surge test was conducted to determine ammonia volatilization rates from tanks at $\mathrm{pH} 6.0,7.0$, and 8.0 before inoculation of bacteria and introduction of fish and plants. Ammonium chloride $(2.5 \mathrm{~g} /$ tank) was added and TAN measurements were taken on 13 July (all tanks reading 6 $\mathrm{mg} \cdot \mathrm{L}$ TAN) and 20 July. Water volume was maintained constant. Ammonia volatilization loss in $\mathrm{mg} \cdot \mathrm{L} \cdot \mathrm{d}$ was determined by subtracting beginning and ending TAN and dividing by 7 .

A complete hydroponic nutrient solution consisting of $200 \mathrm{mg} \cdot \mathrm{L}^{-1}$ NFT Vegetable Formula (Grower's Supply Center, Lynn Haven, FL) was added to each tank on 21 July. The NFT vegetable formula consisted of $6 \mathrm{mg} \cdot \mathrm{L}^{-1}$ nitrate nitrogen, $13 \mathrm{mg} \cdot \mathrm{L}^{-1}$ phosphorus, $45 \mathrm{mg} \cdot \mathrm{L}^{-1}$ potassium, $11 \mathrm{mg} \cdot \mathrm{L}^{-1}$ magnesium, $0.9 \mathrm{mg} \cdot \mathrm{L}^{-1}$ iron, $0.07 \mathrm{mg} \cdot \mathrm{L}^{-1}$ zinc, $0.1 \mathrm{mg} \cdot \mathrm{L}^{-1}$ manganese, $0.02 \mathrm{mg} \cdot \mathrm{L}^{-1} \mathrm{cop}$ per, $0.3 \mathrm{mg} \cdot \mathrm{L}^{-1}$ boron, and $0.02 \mathrm{mg} \cdot \mathrm{L}^{-1}$ molybdenum using potassium sulfate, monopotassium phosphate, magnesium sulfate, potassium nitrate, iron EDTA, zinc EDTA, manganese EDTA, copper EDTA, sodium borate, and sodium molybdate as nutrient sources. In addition to the hydroponic fertilizer blend, $\mathrm{Ca}\left(\mathrm{NO}_{3}\right)_{2}, \mathrm{KNO}_{3}$, and $\mathrm{MgSO}_{4}$ were added when needed based on plant nutritional status and water analysis to maintain plant nutrition and similar soluble salt concentrations among treatments. Sodium bicarbonate $\left(\mathrm{NaHCO}_{3}\right)$ and calcium carbonate $\left(\mathrm{CaCO}_{3}\right)$ were added to tank water during the trial to provide alkalinity.

Nitrifying bacteria were added to the biofilters (except the hydroponic control) on 26 July (170 mL, product no. 239211, Proline Freshwater Nitrifying Bacteria). The bacteria solution contained a mix of $50 \%$ Nitrosomonas $\mathrm{sp}$. and $50 \%$ Nitrobacter $\mathrm{sp}$. with a count of $6.7 \times 10^{4}$ cells $/ \mathrm{mL}$ according to the supplier (Aquatic Eco-systems). Another $50 \mathrm{~mL}$ per tank of Proline Freshwater Nitrifying Bacteria was added on 14, 15, and 16 Aug. to control an ammonia spike after the introduction of fish.

Nile tilapia (Oreochromis niloticus from Harbor Branch Oceanographic Institution, Fort Pierce, FL) were stocked into treatment tanks (except hydroponic control) on 1 to 2 Aug. at a similar density of 15 fish per tank with a mean of $32.4 \mathrm{~g} / \mathrm{fish} / \mathrm{tank}$ and a size range from 8 to $122 \mathrm{~g}$. Care was taken to ensure that the fish size distribution was similar in each tank. Density and size distribution were kept similar among treatments during the trial by periodic restocking to compensate for varying fish mortality among treatments. The fish feed contained $41 \%$ protein and was fed at a rate of $3 \mathrm{~g} / \operatorname{tank} / \mathrm{d}$ for the aquaponic treatments and the aquaculture control. The vigor of the initial fish feeding activity was monitored during five feedings beginning 20 Sept. through 30 Sept. and was rated as $1=$ do not come to feed, $3=$ half strike feed, and $5=$ all strike feed. Final fish weights were obtained on 6 Oct.

Based on previous greenhouse trials (Hochmuth et al., 1996), 'Fitness' (Asgrow Seed Company, St. Louis) European cucumber seeds were planted into the perlite of the biofilter of each plot except the aquaculture control treatment on 4 Aug. Four seeds were planted on each side of the distribution plate for a total of eight seeds per plot. Plant germination was complete in all plots on 7 Aug. [0 d after germination (DAG)]. Starter fertilizer (400 $\mathrm{mL}$ of $2 \mathrm{~g} \cdot \mathrm{L}^{-1} \mathrm{NFT}$ vegetable 
formula) was added to each tank biofilter around the young seedlings to stimulate growth 2 DAG. Plants were thinned to four plants per biofilter 7 DAG. Cucumber vines were trellised to overhead wires and pruned to a single leader stem. Fruit were harvested $36,43,50$, and 58 DAG. Fruits showing poor tip fill or angled fruit greater than $45 \%$ were considered unmarketable.

Concentrations of $\mathrm{NO}_{3}{ }^{-}-\mathrm{N}, \quad \mathrm{NO}_{2}{ }^{-}-\mathrm{N}$, $\mathrm{NH}_{4}{ }^{+}-\mathrm{N}$, and $\mathrm{K}^{+}$in recirculating tank water were measured weekly. Tank water TAN (low range 1.0 to $8.0 \mathrm{mg} \cdot \mathrm{L}^{-1}$ ), nitrite nitrogen (low range, 0.1 to $0.8 \mathrm{mg} \cdot \mathrm{L}^{-1}$ ), and alkalinity were measured with test kits (LaMotte Company, Chestertown, MD). TAN (high range 1.0 to $50.0 \mathrm{mg} \cdot \mathrm{L}^{-1}$ ) and nitrite nitrogen (high range, 0 to $150 \mathrm{mg} \cdot \mathrm{L}^{-1}$ ) were measured using an ion-specific meter (Hanna Instruments USA, Woonsocket, RI). Nitrate nitrogen and potassium were measured using an ionspecific electrode (Cardy meter, range 0 to $9900 \mathrm{mg} \cdot \mathrm{L}^{-1}$; Spectrum Technologies, Plainfield, IL). Water $\mathrm{pH}$ was measured two to six times per week (mean of four measurements) using $\mathrm{pH}$ meter model WD-35624-86 (Oakton Instruments, Vernon Hills, IL). Water-dissolved oxygen, specific conductivity (electrical conductivity), temperature, and salinity were measured once every 2 weeks using a YSI Model $85 \mathrm{~m}$ (YSI, Yellow Springs, $\mathrm{OH}$ ) during midday from $11 \mathrm{Am}$ to 2 PM. Cucumber leaf petiole sap $\mathrm{NO}_{3}{ }^{-}-\mathrm{N}$ and potassium levels were measured beginning on 26 Aug. and every 2 weeks thereafter. One leaf petiole per plot from the most recently fully expanded leaf (from the sixth to eighth leaf below the growing point) was measured using ion-specific electrode Cardy meters (Hochmuth, 2003).

A second ammonia surge test was conducted after the last cucumber harvest to determine ammonia biofiltration rates from treatment tanks. Ammonium chloride (3 g/ tank for all treatments except hydroponic control, which received $1 \mathrm{~g} / \mathrm{tank}$ as a result of the presence of residual TAN from applied fertilizer) was added at 11:30 AM on 10 Oct. TAN measurements were taken at 12:00 PM 10 Oct. and every $6 \mathrm{~h}$ thereafter for $24 \mathrm{~h}$. Recirculating tanks were maintained at a constant water volume of $100 \mathrm{~L}$. Ammonia biofiltration rates in $\mathrm{mg} \cdot \mathrm{L}^{-1} \cdot \mathrm{d}^{-1}$ were determined by subtracting beginning and ending TAN except for aquaponic treatment $\mathrm{pH}$ 8.0, which was determined by subtracting beginning TAN from the first 6-h TAN measurement and multiplying by 4 because TAN was resolved to zero in this treatment at $12 \mathrm{~h}$.

End-of-season MPN estimates of the Nitrosomonas sp. bacterial cell populations in the biofilters were made using the threetube serial dilution method (Feng, 2001). Core samples of $200 \mathrm{~mL}$ perlite were taken from the middle of each biofilter on 12 Oct. Samples were mixed into a composite for each treatment and refrigerated at $5{ }^{\circ} \mathrm{C}$. Nitrifier culture medium for Nitrosomonas sp. was prepared and autoclaved as described (ATCC, 2006) on 17 Oct. Ninety growout and 10 inoculation test tubes were prepared for each of the five treatments. The ATCC liquid medium in the test tubes measured $0 \mathrm{mg} \cdot \mathrm{L}^{-1}$ for $\mathrm{NO}_{2}{ }^{-} \mathrm{N}$ and $5 \mathrm{mg} \cdot \mathrm{L}^{-1}$ for $\mathrm{NO}_{3}{ }^{-}$$\mathrm{N}$ before inoculation with nitrifying bacteria core samples. Growout test tubes were replicated three times with 30 test tubes per replicate per treatment. On 21 Oct., 200-mL subsamples of perlite from each treatment were mixed with $200 \mathrm{~mL}$ deionized water and blended in a laboratory blender (Hamilton Beech, Washington, NC) for $30 \mathrm{~s}$. One milliliter of this blended solution was used to inoculate MPN test tubes. Tubes were shaken $8 \mathrm{~h} \cdot \mathrm{d}^{-1}$ for $30 \mathrm{~d}$ and then measured for nitrifier activity. A measurement $0.1 \mathrm{mg} \cdot \mathrm{L}^{-1} \mathrm{NO}_{2}{ }^{-} \mathrm{N}$ or greater or $10 \mathrm{mg} \cdot \mathrm{L}^{-1} \mathrm{NO}_{3}{ }^{-} \mathrm{N}$ or greater was considered positive for Nitrosomonas bacteria activity (Eq. 1 and Eq. 2). $\mathrm{NO}_{2}{ }^{-} \mathrm{N}$ (low range, 0.1 to $0.8 \mathrm{mg} \cdot \mathrm{L}^{-1}$ ) was measured with a test kit (LaMotte Company) and $\mathrm{NO}_{3}{ }^{-}$$\mathrm{N}$ was measured using an ion specific electrode (Cardy meter, range 0 to $9900 \mathrm{mg} \cdot \mathrm{L}^{-1}$ ). One measurement for each replicate (three measurements per treatment) was recorded based on statistical tables (Feng, 2001) to determine bacteria cell population number.

Treatments were arranged in a randomized complete block design with four replications. Data were analyzed using analysis of variance (SAS Institute, Inc., 2004) and Duncan's multiple range test at the 0.05 level. Linear content over the nonrepeating equal interval $\mathrm{pH}$ units (excluding the hydroponic and aquaculture control treatments) were calculated (Gomez and Gomez, 1984).

\section{Results and Discussion}

Table 1 summarizes the season mean tank water TAN, $\mathrm{NO}_{2}{ }^{-}-\mathrm{N}$, and $\mathrm{CaCO}_{3}$ equivalent alkalinity as well as the operating $\mathrm{pH}$ ranges for each treatment. Nitrification is an acidproducing process (ammonia oxidation produces protons $\mathrm{H}^{+}$in Eq. 1) requiring adjustment of recirculating water to maintain target total marketable yield when cucumbers were grown in hydroponic or aquaponic production systems at $\mathrm{pH}$ 6.0. These results indicate an early yield (first harvest) advantage in keeping nutrient solution $\mathrm{pH}$ between 6.0 and 7.0 , but not an advantage for total season marketable yield. This would indicate that keeping the recirculating $\mathrm{pH}$ at 7.5 to 8.0 to accommodate nitrifying bacteria activity would negatively affect early but not total yield.

Nitrifying activity is commonly determined by measuring ammonia oxidation (substrate TAN loss), intermediate (nitrite) and end product (nitrate) accumulation, or oxygen uptake (Hagopian and Riley, 1998; Prosser, 1986). Ammonia biofiltration rate of the perlite trickling biofilters in aquaponic production was determined by measuring TAN loss during a 24-h period after introduction of ammonia to the system water. This ammonia surge test was conducted after the last cucumber fruit harvest. TAN loss from aquaponic system water was $3.8,6.1$, and $16 \mathrm{mg} \cdot \mathrm{L}^{-1} \cdot \mathrm{d}^{-1}$ for $\mathrm{pH} 6.0,7.0$, and 8.0 treatments, respectively (Table 4 ). This compared with TAN loss of $1.3 \mathrm{mg} \cdot \mathrm{L}^{-1} \cdot \mathrm{d}^{-1}$ for the hydroponic control and $5.9 \mathrm{mg} \cdot \mathrm{L} \cdot \mathrm{d}$ for the aquaculture control. TAN loss from the aquaponic treatments increased linearly at 6 , 12 , and $18 \mathrm{~h}$ after introduction of ammonia as the $\mathrm{pH}$ increased from 6.0 to 8.0. This linear increase in TAN loss may be the result of an increased unionized ammonia substrate $\left(\mathrm{NH}_{3}\right.$; Eq. [1]) concentration resulting from increasing $\mathrm{pH}$ (Francis-Floyd and Watson, 1996). Increased biofilter activity occurs with an increase in substrate $\left(\mathrm{NH}_{3}\right)$ concentration (Hagopian and Riley, 1998). During a similar ammonia surge test at the beginning of the experiment after system setup but before inoculation with bacteria, the maximum volatilization loss of TAN from these tanks was $0.39,0.53$, and $0.63 \mathrm{mg} \cdot \mathrm{L}^{-1} \cdot \mathrm{d}^{-1}$ for $\mathrm{pH} 6.0$, 7.0 , and 8.0 , respectively. Because average

Table 1. System season average $\mathrm{TAN}, \mathrm{NO}_{2}{ }^{-}-\mathrm{N}, \mathrm{CaCO}_{3}{ }^{\mathrm{z}}$, and $\mathrm{pH}$ range in treatment tanks.

\begin{tabular}{|c|c|c|c|c|c|c|}
\hline \multirow[b]{2}{*}{ System $^{y}$} & \multirow[b]{2}{*}{$\mathrm{pH}$} & \multirow{2}{*}{$\begin{array}{c}\text { TAN } \\
\left(\mathrm{mg} \cdot \mathrm{L}^{-1}\right)\end{array}$} & \multirow{2}{*}{$\begin{array}{l}\mathrm{NO}_{2}{ }^{-}-\mathrm{N} \\
\left(\mathrm{mg} \cdot \mathrm{L}^{-1}\right)\end{array}$} & \multirow{2}{*}{$\begin{array}{c}\mathrm{CaCO}_{3} \\
\left(\mathrm{mg} \cdot \mathrm{L}^{-1}\right)\end{array}$} & \multicolumn{2}{|c|}{$\mathrm{pH}$} \\
\hline & & & & & $\overline{\text { Low }}$ & $\overline{\text { High }}$ \\
\hline Aquaponic & 6.0 & 2.1 & 0.2 & 35 & 5.5 & 6.7 \\
\hline Aquaponic & 7.0 & 0.7 & 1.8 & 42 & 6.5 & 7.5 \\
\hline Aquaponic & 8.0 & 0.3 & 1.4 & 84 & 7.1 & 8.3 \\
\hline Hydroponic & 6.0 & 3.0 & 0.0 & 39 & 5.5 & 6.8 \\
\hline Aquaculture & 7.0 & 0.7 & 2.1 & 41 & 6.5 & 7.4 \\
\hline
\end{tabular}

zTAN = total ammonia nitrogen; $\mathrm{NO}_{2}{ }^{-} \mathrm{N}=$ nitrite nitrogen; $\mathrm{CaCO}_{3}=$ calcium carbonate.

${ }^{\mathrm{y}}$ Aquaponic $=$ with plants, fish, and nitrifying bacteria; hydroponic $=$ with plants alone; aquaculture $=$ with fish and nitrifying bacteria.

pH levels. Table 2 summarizes monthly average high and low greenhouse air temperatures, average tank water temperatures, and oxygen levels.

Early marketable cucumber yield decreased linearly from 1.52 to $0.67 \mathrm{~kg} /$ plant as $\mathrm{pH}$ increased from 6.0 to 8.0 (Table 3). Total marketable and cull yields were not significantly different among treatments $(P=$ $0.05)$. There was no difference in early or
Table 2. Monthly average greenhouse air temperature, tank water temperature, and tank water oxygen level.

\begin{tabular}{|c|c|c|c|c|}
\hline \multirow[b]{3}{*}{ Month } & & & \multicolumn{2}{|c|}{ Tank water } \\
\hline & \multicolumn{2}{|c|}{ Air temp $\left({ }^{\circ} \mathrm{C}\right)$} & \multirow{2}{*}{$\begin{array}{c}\text { Temp } \\
\left({ }^{\circ} \mathrm{C}\right)\end{array}$} & \multirow{2}{*}{$\begin{array}{l}\text { Oxygen } \\
\left(\mathrm{mg} \cdot \mathrm{L}^{-1}\right)\end{array}$} \\
\hline & High & Low & & \\
\hline July & 35 & 24 & 27 & 5.5 \\
\hline August & 38 & 24 & 29 & 4.6 \\
\hline September & 32 & 24 & 26 & 3.9 \\
\hline October & 29 & 19 & 23 & 4.4 \\
\hline
\end{tabular}


Table 3. Fitness cucumber fruit yield response to water $\mathrm{pH}$ and production system.

\begin{tabular}{|c|c|c|c|c|c|c|c|}
\hline \multirow[b]{2}{*}{ System $^{\mathrm{y}}$} & \multirow[b]{2}{*}{$\mathrm{pH}$} & \multicolumn{2}{|c|}{ Early mark ${ }^{z}$} & \multicolumn{2}{|c|}{ Total mark } & \multicolumn{2}{|c|}{ Total cull } \\
\hline & & (kg/plant) & $\overline{\text { (no./plant) }}$ & (kg/plant) & (no./plant) & (kg/plant) & (no./plant) \\
\hline Aquaponic & 6.0 & $1.52 \mathrm{a}^{\mathrm{x}}$ & $3.3 \mathrm{a}$ & $3.64 \mathrm{a}$ & $8.3 \mathrm{a}$ & $0.44 \mathrm{a}$ & $3.3 \mathrm{a}$ \\
\hline Aquaponic & 7.0 & $1.32 \mathrm{a}$ & $2.9 \mathrm{a}$ & $4.12 \mathrm{a}$ & $9.7 \mathrm{a}$ & $0.33 \mathrm{a}$ & $3.0 \mathrm{a}$ \\
\hline Aquaponic & 8.0 & $\begin{array}{c}0.67 \mathrm{~b} \\
\mathrm{~L}^{* * w}\end{array}$ & $\begin{array}{c}1.8 \mathrm{~b} \\
\mathrm{~L}^{*}\end{array}$ & $3.54 \mathrm{a}$ & $8.8 \mathrm{a}$ & $0.33 \mathrm{a}$ & $3.0 \mathrm{a}$ \\
\hline Hydroponic & 6.0 & $1.57 \mathrm{a}$ & $3.3 \mathrm{a}$ & $3.63 \mathrm{a}$ & $8.4 \mathrm{a}$ & $0.53 \mathrm{a}$ & $3.9 \mathrm{a}$ \\
\hline Aquaculture & - & - & - & - & - & - & - \\
\hline
\end{tabular}

${ }^{\mathrm{z}}$ Early $=$ first harvest $-36 \mathrm{DAG}$; total = four harvests - 36, 43, 50, 58 DAG, kilograms and number of fruit per plant. Marketable fruit $=34$ to $42 \mathrm{~cm}$ length, less than $45^{\circ}$ angle, few blemishes; Cull $=$ greater than $45^{\circ}$ angle, poor tip fill, excess blemishes. Average of four plants per plot, four replicates.

${ }^{\mathrm{y}}$ Aquaponic $=$ with plants, fish, and nitrifying bacteria; hydroponic $=$ with plants; aquaculture $=$ with fish and nitrifying bacteria.

${ }^{\mathrm{x}}$ Within columns, means followed by different letters are significantly different at the 0.05 level; four replicates.

${ }^{\mathrm{w}} \mathrm{pH}$ effects of aquaponic systems were significantly linear at the $5 \%(*)$ or $1 \%(* *)$ level.

$\mathrm{DAG}=$ days after germination

Table 4. Twenty-four-hour total ammonia nitrogen (TAN) and nitrite nitrogen $\left(\mathrm{NO}_{2}^{-}-\mathrm{N}\right)$ concentrations in a perlite trickling biofilter after introduction of ammonium chloride.

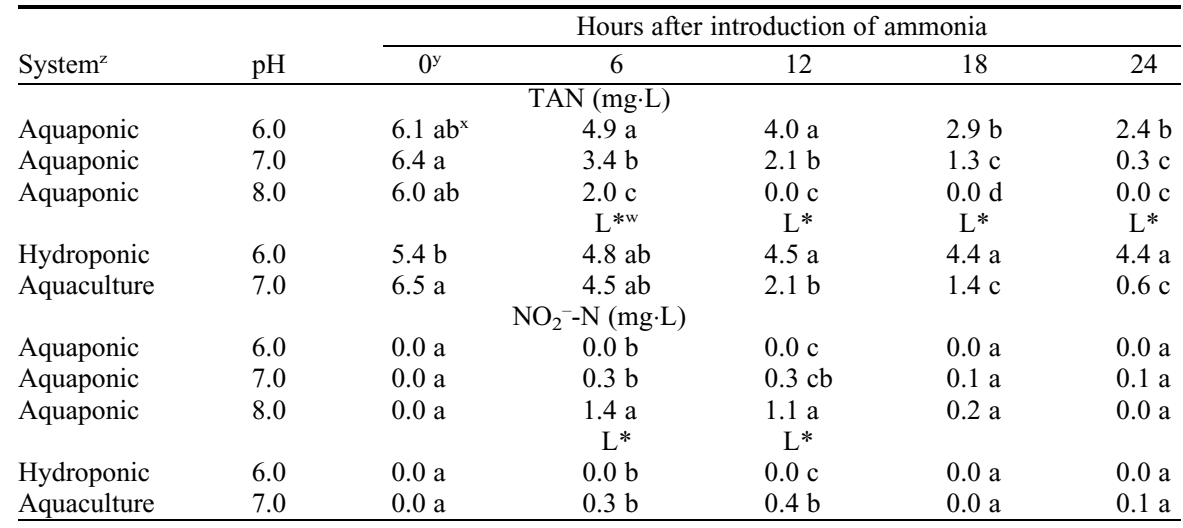

${ }^{\mathrm{z}}$ Aquaponic $=$ with plants, fish, and nitrifying bacteria; hydroponic $=$ with plants; aquaculture $=$ with fish and nitrifying bacteria.

${ }^{\mathrm{y}}$ Ammonium chloride introduced into the recirculating tanks.

${ }^{\mathrm{x}}$ Within columns, means followed by different letters are significantly different at the 0.05 level; four replicates.

${ }^{\mathrm{w}} \mathrm{pH}$ effects of aquaponic systems were significantly linear at the $1 \%(*)$ level.

greenhouse temperatures were $6{ }^{\circ} \mathrm{C}$ cooler during the second ammonia surge test and volatilization decreases with decreasing temperatures, it is likely that the actual ammonia biofiltration is very near the measured TAN loss in Table 4 for each treatment.

Considering TAN loss as a function of biofilter media volume $(20 \mathrm{~L})$, these results convert to 19,31 , and $80 \mathrm{~g} \cdot \mathrm{m}^{-3} \cdot \mathrm{d}^{-1}$, respectively, for the aquaponic treatments $\mathrm{pH} 6.0$, 7.0, and 8.0 (Fig. 1). This compares to $6 \mathrm{~g} \cdot \mathrm{m}^{-3} \cdot \mathrm{d}^{-1}$ for the hydroponic control and $29 \mathrm{~g} \cdot \mathrm{m}^{-3} \cdot \mathrm{d}^{-1}$ for the aquaculture control. The recommended ammonia biofiltration rate for trickling biofilters in aquaculture production is $90 \mathrm{~g} \cdot \mathrm{m}^{-3} \cdot \mathrm{d}^{-1}$ (Losordo et al., 1999). Thus, at $\mathrm{pH} \mathrm{8.0,} \mathrm{the} \mathrm{perlite} \mathrm{trickling} \mathrm{biofilter/root}$ growth medium is functioning at near optimum for trickling biofilters. Comparing 6 $\mathrm{g} \cdot \mathrm{m}^{-3} \cdot \mathrm{d}^{-1}$ (TAN removal with cucumber plants only) and $19 \mathrm{~g} \cdot \mathrm{m}^{-3} \cdot \mathrm{d}^{-1}$ (with plants and nitrifying bacteria) at $\mathrm{pH} 6.0$ indicates that the aquaponic biofilter was three times more efficient as plants alone in the biofilter in removing ammonia from aquaponic system water under these conditions. In addition, there was no significant difference $(P=0.05)$ in TAN loss between the aquaculture control and the aquaponic treatment when both were at $\mathrm{pH} 7.0$ (Fig. 1), which again emphasizes the importance of nitrification over plant uptake for biofiltration of ammonia. More work should be done to test the nitrification/ plant biofiltration relationship on TAN re-

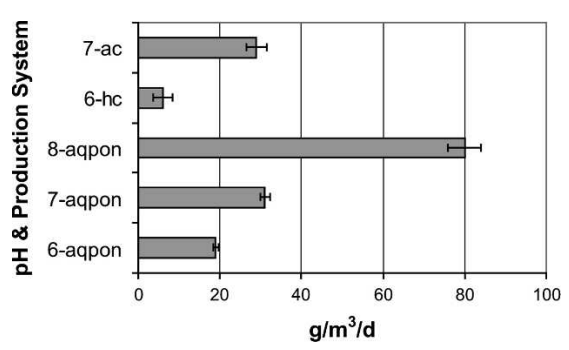

Fig. 1. Perlite trickling biofilter 24-hour total ammonia nitrogen loss as influenced by $\mathrm{pH}$ and production system. Note: 6.0-aqpon, 7.0aqpon, 8.0 -aqon $=$ aquaponic system $\mathrm{pH}$ with plants, fish, and nitrifying bacteria; $6.0-\mathrm{hc}=\mathrm{pH}$ hydroponic control with plants; $7.0-\mathrm{ac}=\mathrm{pH}$ aquaculture control with fish and nitrifying bacteria. Error bars represent $\pm_{S E}(n=4)$. moval during early-season active stages of plant growth, because the current test was done after the last cucumber harvest when plants were fully mature but not actively growing.

Recirculating aquaculture systems are usually intensively managed with maximum carrying capacities of $60 \mathrm{~g}$ fish per liter of water for systems with oxygen injection and $30 \mathrm{~g} \cdot \mathrm{L}^{-1}$ for natural air-aerated systems (Masser et al., 1999; M. Davis, personal communication). The ammonia biofiltration rate of the designed biofilter in this experiment (perlite volume:tank water volume ratio of 1:5) was sufficient to oxidize ammonia from a naturally aerated system at maximum carrying capacity with production water at $\mathrm{pH} 8.0$, but not when operating at $\mathrm{pH} 7.0$ or 6.0. Thus, the perlite medium biofilter volumes would most likely need to be increased to compensate for reduced biofiltration rates at lower operating water $\mathrm{pH}$ levels.

Results of MPN bacterial cell counts from biofilter core sampling indicate that the aquaculture control without plants in the biofilter had a significantly higher $(P=0.01 \%)$ number of Nitrosomonas sp. bacteria compared with treatments containing plants in the biofilter (Fig. 2). In other work, numbers of nitrifying bacteria (Nitrosomonas europaea) were reduced 200-fold in the presence of plants roots compared with without them (Verhagen et al., 1994). In the current trial, the aquaponic system at $\mathrm{pH} 8.0$ had the highest ammonia biofiltration rate of all treatments (Fig. 1). Hence, MPN bacteria counts now (Fig. 2) were not a good indicator of biofilter performance (Fig. 1). This indicates that $\mathrm{pH}$ of system water was a more important factor in determining efficiency of microbial activity in the biofilter rather than bacterial species density. The increased activity was most likely the result of $\mathrm{pH}$-induced increases in unionized ammonia substrate available for the nitrification reaction [Eq. 1] as the $\mathrm{pH}$ increases. It would be beneficial to take MPN counts over time during the growing season to more accurately predict the systems effect on their numbers and activity. The hydroponic control was not inoculated with nitrifying bacteria, but the MPN test indicated a low

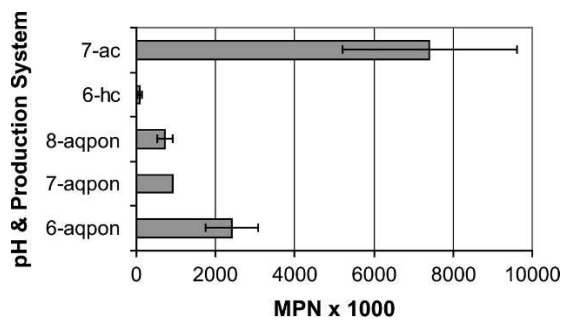

Fig. 2. Most probable number (MPN) of Nitrosomonas sp. bacteria in perlite trickling biofilters as influenced by $\mathrm{pH}$ and production system. Note: 6.0-aqpon, 7.0-aqpon, 8.0-aqon $=$ aquaponic system $\mathrm{pH}$ with plants, fish, and nitrifying bacteria; $6.0-\mathrm{hc}=\mathrm{pH}$ hydroponic control with plants; $7.0-\mathrm{ac}=\mathrm{pH}$ aquaculture control with fish and nitrifying bacteria. Error bars represent $\pm \operatorname{SE}(n=3)$. 
Table 5. Tilapia mean weight, initial feeding activity, and overall mortality as influenced by water $\mathrm{pH}$ and production system.

\begin{tabular}{|c|c|c|c|c|c|}
\hline System ${ }^{z}$ & $\mathrm{pH}$ & $\begin{array}{l}\text { Mean stocking } \\
\text { wt. g/fish }\end{array}$ & $\begin{array}{l}\text { Mean final } \\
\text { wt. g/fish }\end{array}$ & $\begin{array}{c}\text { Initial }^{\mathrm{y}} \\
\text { feeding activity }\end{array}$ & $\begin{array}{c}\text { Fish }^{\mathrm{x}} \\
\text { mortality }\end{array}$ \\
\hline Aquaponic & 6.0 & $37 a$ & $79 a$ & $1.6 \mathrm{~b}^{\mathrm{w}}$ & $18.5 \mathrm{a}$ \\
\hline Aquaponic & 7.0 & $39 a$ & $72 \mathrm{a}$ & $2.3 \mathrm{ab}$ & $8.0 \mathrm{~b}$ \\
\hline Aquaponic & 8.0 & $37 \mathrm{a}$ & $65 \mathrm{a}$ & $\begin{array}{r}4.0 \mathrm{a} \\
\mathrm{L}^{* v}\end{array}$ & $\begin{array}{c}3.4 \mathrm{~b} \\
\mathrm{~L}^{*}\end{array}$ \\
\hline Hydroponic & - & - & - & - & - \\
\hline
\end{tabular}

${ }^{\mathrm{z}}$ Aquaponic $=$ with plants, fish, and nitrifying bacteria; hydroponic $=$ with plants; aquaculture $=$ with fish and nitrifying bacteria.

${ }^{y}$ Initial feeding activity rating: $1=$ do not come to feed; $3=$ half strike feed; $5=$ all strike feed.

${ }^{\mathrm{x}}$ Average number dead at end of growing season.

${ }^{w}$ Within columns, means followed by different letters are significantly different at the 0.05 level; four replicates.

${ }^{\mathrm{p}} \mathrm{pH}$ effects of aquaponic systems were significantly linear at the $1 \%(*)$ level.

level of bacteria- 2 cells $/ \mathrm{mL}$ of perlite. Therefore, some unintentional or low-level natural inoculation occurred during the growing season. To maximize the ammonia biofiltration rate, system operating $\mathrm{pH}$ should be maintained near 8.0 provided it does not adversely impact the plant or fish yield.

Although no differences in tilapia growth were expected among treatments resulting from their adaptation to wide ranges of water quality conditions (Chapman, 2000; Lim and Webster, 2006; Popma and Masser, 1999; Watanabe et al., 1997), significant differences in initial feeding activity and fish mortality $(P=0.05)$ were observed (Table 5). Initial feeding activity, or the vigor response of fish when feed is first thrown into the recirculating tanks, increased and fish mortality decreased as $\mathrm{pH}$ increased from 6.0 to 8.0. The vigor of fish feeding activity is a reflection of the general health and stress level of the fish (Lim and Webster, 2006). These results imply that fish were healthier, under less environmental stress, and more likely to survive as $\mathrm{pH}$ increased from 6.0 to 8.0. Fish density and feeding rate were kept the same among the aquaponic and aquaculture control treatments so that ammonia generation by the fish would not be a variable in the biofiltration rate. This required periodic restocking of these tanks as a result of variable mortality among treatments. Final total fish biomass was 316,324 , and $325 \mathrm{~g}$ for the aquaponic treatments at $\mathrm{pH} 6.0,7.0$, and 8.0 , respectively. This compared with $317 \mathrm{~g}$ for the aquaculture control. Mean final fish weights ( $g /$ fish) were not significantly different among these treatments (Table 5). Ammonium and nitrate-containing fertilizers were periodically added to the hydroponic control treatment to keep the level of these nutrients similar to those being generated in the aquaponic and aquaculture control treatments. This ensured that $\mathrm{pH}$ would be the main variable affecting the ammonia biofiltration rate.

\section{Conclusion}

Biofilter removal of TAN increased linearly in a perlite trickling biofilter/root growth medium and occurred at the rate of 19,31 , and $80 \mathrm{~g} \cdot \mathrm{m}^{-3} \cdot \mathrm{d}^{-1}$ for aquaponic systems operating at $\mathrm{pH} 6.0,7.0$, and 8.0, respectively. Maximum TAN removal $\left(80 \mathrm{~g} \cdot \mathrm{m}^{-3} \cdot \mathrm{d}^{-1}\right.$ at $\mathrm{pH}$ 8.0) was similar to reported trickling biofilter removal rates in aquaculture. The difference in TAN loss at $\mathrm{pH} 7.0$ between the aquaculture control (tilapia and nitrifying bacteria) and the aquaponic system (tilapia, nitrifying bacteria, and cucumber) were not significant. Thus, under these experimental conditions, nitrification was more important than plant uptake for biofiltration of ammonia. MPN analysis of Nitrosomonas sp. bacteria populations indicated a significantly higher population of bacteria in biofilters without plant roots. However, the highest TAN loss occurred in the aquaponic system produced at $\mathrm{pH}$ 8.0. Thus, operating $\mathrm{pH}$ was more important than nitrifying bacteria population in system TAN loss. Fish vigor increased as $\mathrm{pH}$ increased from 6.0 to 8.0. Early marketable aquaponic cucumber yield decreased linearly as $\mathrm{pH}$ increased from 6.0 to 8.0. However, there were no differences in total marketable cucumber yields among treatments. Results indicate that given the importance of $\mathrm{pH}$ in biofilter activity and no difference in total cucumber yields in a $\mathrm{pH}$ range of 6.0 to 8.0 , then recirculating aquaponic systems using cucumber and tilapia with high densities of fish should be managed with $\mathrm{pH}$ closer to those favoring nitrification (7.5 to 8.0) to efficiently convert waste ammonia to nitrate nitrogen.

\section{Literature Cited}

Adler, P. 2001. Overview of economic evaluation of phosphorus removal by plants. Aquaponics J. 5:15-18.

Adler, P.R., J.K. Harper, F. Takeda, E.D. Wade, and S.T. Summerfelt. 2000. Economic evaluation of hydroponics and other treatment options for phosphorus removal in aquaculture effluent. HortScience 35:993-999.

Adler, P.R., F. Takeda, D.M. Glenn, and S.T. Summerfelt. 1996. Utilizing byproducts to enhance aquaculture sustainability. World Aquaculture 27:24-26.

ATCC. 2006. ATCC 221 Nitrosomonas. American Type Culture Collection, Manassas, VA. 2 Oct. 2006. <http://www.bibliographics.com/LAB/ PCR/NITRIFIER\%20CULTURE\%20MEDIA. $\mathrm{htm}>$.

Campbell, N.A. and J.B. Reese. 2002. Biology. 6th Ed. Pearson Education Inc. (Benjamin Cummings), San Francisco, CA.
Chapman, F.A. 2000. Culture of hybrid tilapia: A reference profile. Circular 1051. Department of Fisheries and Aquatic Sciences, Florida Cooperative Extension Service, Institute of Food and Agricultural Sciences, University of Florida, Gainesville, FL. 5 Apr. 2007. <http://edis.ifas. ufl.edu/FA012>.

Colt, J.E. and G. Tchobanoglous. 1976. Evaluation of the short-term toxicity of nitrogenous compounds to channel catfish, Ictalurus punctatus. Aquaculture 8:209-224.

Debusk, W.F. 1999. Wastewater treatment wetlands: Contaminant removal processes. Fact Sheet SL155. Department of Soil and Water Sciences, Florida Cooperative Extension Service, Institute of Food and Agricultural Sciences, University of Florida, Gainesville, FL. 3 July 2007. <http://edis.ifas.ufl.edu/SS293>.

Feng, P. 2001. Most probable number from serial dilutions. Bacterial analytical manual online. U.S. Food and Drug Administration., Final revision: 2001 Jan. 25. 2 Jan. 2007. <http:// www.cfsan.fda.gov/ ebam/bam-a2.html $>$.

Feray, C., B. Volat, V. Derange, A. Clays-Josserand, and B. Montuelle. 1999. Assessment of three methods for detection and quantification of nitrite-oxidizing bacteria and Nitrobacter in freshwater sediments (MPN-PCR, MPN-Griess, Immunofluorescence). Microb. Ecol. 37:208217.

Francis-Floyd, R. and C. Watson. 1996. Ammonia. FA-16. Department of Fisheries and Aquatic Sciences, Florida Cooperative Extension Service, University of Florida, Gainesville, FL. 5 Apr. 2007. <http://edis.ifas.ufl.edu/FA031>.

Gold, M.V. 1999. Sustainable agriculture: Definitions and terms. Alternative Farming Systems Information Center, National Agricultural Library, Beltsville, MD. 2 July 2007. <http://www.nal. usda.gov/afsic/AFSIC_pubs/srb9902.htm>.

Gomez, K.A. and A.A. Gomez. 1984. Statistical procedures for agricultural research. John Wiley \& Sons, New York, NY.

Gutierrez-Wing, M. and R.F. Malone. 2006. Biological filters in aquaculture: Trends and research directions for freshwater and marine applications. Aquacultural Engineering 34: 163-171.

Hagopian, D.S. and J.G. Riley. 1998. A closer look at the bacteriology of nitrification. Aquacultural Engineering 18:223-244.

Hochheimer, J.N. and F. Wheaton. 1998. Biological filters: Trickling and RBC design. Proc. Second International Conference of Recirculating Aquaculture. p. 291-318.

Hochmuth, G. 2003. Plant petiole sap-Testing for vegetable crops. CIR1144. Horticultural Sciences Department, Florida Cooperative Extension Service, University of Florida, Gainesville, FL. 7 Feb. 2008. <http://edis.ifas. ufl.edu/CV004>.

Hochmuth, G.J. 2001. Fertilizer management for greenhouse vegetables, Florida greenhouse vegetable production handbook, volume 3 . HS787. Horticultural Sciences Department, Florida Cooperative Extension Service, University of Florida, Gainesville, FL. 5 Apr. 2007. $<$ http://edis.ifas.ufl.edu/CV265>.

Hochmuth, R.C., L.L. Davis, and G.J. Hochmuth. 1996. Evaluation of twelve greenhouse cucumber cultivars and two training systems over two seasons in Florida. North Florida Research and Education Center, Suwannee Valley. Research Report 96-10. 5 Apr. 2007. <http://nfrec-sv. ifas.ufl.edu/Reports\%20HTML/96-10_report. htm>.

Lang, H.J. and G.S. Elliott. 1997. Enumeration and inoculation of nitrifying bacteria in soilless 
potting media. J. Amer. Soc. Hort. Sci. 122:709-714.

Lim, C. and C.D. Webster. 2006. Tilapia: Biology, culture, and nutrition. The Food Products Press, Binghamton, NY.

Lin, Y.F., S.R. Jing, D.Y. Lee, and T.W. Wang. 2002. Nutrient removal from aquaculture wastewater using a constructed wetlands system. Aquaculture 209:169-184.

Losordo, T.M., M.P. Masser, and J.E. Rakocy. 1999. Recirculating aquaculture tank production systems: A review of component options. Southern Regional Aquaculture Center Publication No. 453 .

Madigan, M.T., J.M. Martinko, and J. Parker. 2003. Brock biology of microorganisms. 10th Ed. Pearson Education, Inc., Upper Saddle River, NJ.

Marschner, H. 2003. Mineral nutrition of higher plants. Academic Press, Elsevier Science Ltd., San Diego, CA.

Masser, M.P., J. Rakocy, and T.M. Losordo. 1999. Recirculating aquaculture tank production systems: Management of recirculating systems. Southern Regional Aquaculture Center Publication No. 452.

Mitsch, W.J. and J.G. Gosselink. 2000. Wetlands. 3rd Ed. John Wiley \& Sons, Inc., New York, NY.
Papen, H. and R. von Berg. 1998. A most probable number method (MPN) for the estimation of cell numbers of heterotrophic nitrifying bacteria in soil. Plant Soil 199:123-130.

Popma, T. and M. Masser. 1999. Tilapia: Life history and biology. Southern Regional Aquaculture Center Publication No. 283, Stoneville, MS.

Prosser, J.I. 1986. Nitrification. Society for Microbiology, Special Publication Volume 20.

Resh, H.M. 2004. Hydroponic food production. 6th Ed. New Concept Press Publishing Co., Mahwah, NJ.

Rijn, J.V. and G. Rivera. 1990. Aerobic and anaerobic biofiltration in an aquaculture unit-Nitrite accumulation as a result of nitrification and denitrification. Aquacultural Engineering 9:217-234.

SAS Institute, Inc. 2004. SAS/STAT ${ }^{\circledR} 9.1$ user's guide. SAS Institute Inc., Cary, NC.

Schwarz, D., S. Ruppel, and R. Kuchenbuch. 1999. Nitrogen cycle and microorganisms in a hydroponic system as influenced by the amount of nitrogen applied. Proc. Int. Sym. Growing Media and Hydroponics. Acta Hort. 481:371377.

Smither-Kopperl, M.L. and D.J. Cantliffe. 2004. Protected agriculture as a methyl bromide alternative? Current reality and future promise. Proc. Fla. State Hort. Soc. 117:21-27.

Smorczewski, W.T. and E.L. Schmidt. 1991. Numbers, activities, and diversity of autotrophic ammonia-oxidizing bacteria in a freshwater, eutrophic lake sediment. Can. J. Microbiol. 37:828-833.

Timmons, M.B., J.M. Ebeling, F.W. Wheaton, S.T. Summerfelt, and B.J. Vinci. 2002. Recirculating aquaculture systems. 2nd ed. Northeast Regional Aquaculture Center Publication No. $01-002$.

Tyson, R.V., R.C. Hochmuth, E.M. Lamb, G.J. Hochmuth, and M.S. Sweat. 2001. A decade of change in Florida's greenhouse vegetable industry: 1991-2001. Proc. Fla State Hort. Soc. 114:280-283.

Verhagen, F.J.M., P.E.J. Hageman, J.W. Woldendorp, and H.J. Laanbroek. 1994. Competition for ammonium between nitrifying bacteria and plant roots in soil pots; effects of grazing flagellates and fertilization. Soil Biol. Bioch. 26:89-96.

Watanabe, W.O., B.L. Olla, R.I. Wicklund, and W.D. Head. 1997. Saltwater culture of Florida red tilapia and other saline-tolerant tilapias: A review. World Aquaculture Society, Tilapia Aquaculture in the Americas 1:54-141. 